\title{
Occult Hepatitis B Reactivation
}

\section{Okült Hepatit B Reaktivasyonu}

\author{
Murat AFYON1, Cumhur ARTUK2 \\ ${ }^{1}$ Gülhane Military Medical Academy Haydarpaşa Teaching Hospital, Primary Care Inspection, Clinic of Family Health Center and the Naval Academy, Istanbul, Turkey \\ ${ }^{2}$ Gülhane Military Medical Academy Training and Research Hospital, Clinic of Infectious Diseases, Ankara, Turkey
}

Anahtar Kelimeler: Okült hepatit B, HBV DNA, HBV reaktivasyonu

Keywords: Occult hepatitis B, HBV DNA, HBV reactivation

\section{Dear Editor,}

In the recent issue of the Viral Hepatitis Journal, we read with interest the article by Uyanıkoglu et al. (1), "Occult Hepatitis B Reactivation After Chemotherapy: A Case Report". In addition to this article, we wanted to emphasize a few additional important points about the subject.

First of all, definition of occult hepatitis B virus (OHB) infection is long-lasting presence of hepatitis B virus (HBV) deoxyribonucleic acid (DNA) in the liver with detectable (usually very low, $<200 \mathrm{lU} / \mathrm{ml}$ ) or undetectable HBV DNA in the serum of individuals testing hepatitis B surface antigen ( $\mathrm{HBsAg}$ ) negative by currently available assays (2). OHB has been reported in several clinical contexts. However, OHB is most commonly associated with "anti-HBc alone" or "isolated anti-HBc positivity", particularly in endemic areas (3). Another situation labelled "false" OHB with serum HBV DNA levels comparable to the different phases of overt HBV infection could be encountered due to infection by HBV variants with mutations in the "a" determinant region producing a modified $\mathrm{HBsAg}$ that is not recognized by some or all available assays (2).

It is a general opinion that the molecular basis of $\mathrm{OHB}$ is long-term presence of covalently closed circular DNA (cccDNA) in the nucleus of hepatocyte and also, several possibilities like mutations in the HBV genome, coinfection with hepatitit $\mathrm{C}$ virus (HCV), human immunodeficiency virus (HIV) or Schistosoma mansoni, deamination by apolipoprotein B mRNA editing enzyme catalytic polypeptide (APOBEC), reduction of host immune response, epigenetic changes due to acetylation, phosphorylation or methylation, integration into the host genome, immune complex formation, and HBV infection in peripheral blood mononuclear cells have been hypothesized as the mechanisms of $\mathrm{OHB}(4)$.

The clinical significance of OHB remains unclear. However, it is considered that $\mathrm{OHB}$ can be a risk factor for transmission of HBV as well as cryptogenic liver disease, reactivation of HBV, hepatocellular carcinoma, in addition, OHB may affect disease progression and treatment response in chronic $\mathrm{HCV}(2,3,4,5,6)$.

Although reactivation of $\mathrm{HBV}$ in patients with $\mathrm{OHB}$ is rarer than in those with $\mathrm{HBsAg}$ positivity, there is a higher risk for mortality and morbidity in patients with $\mathrm{OHB}$ (3). $\mathrm{OHB}$ reactivation can be associated with cancer therapy, autoimmune diseases, HIV infection, organ transplantation, hematological malignancies and use of immunosuppressive drugs or histone deacetylase inhibitors (Table 1) (5). Other risk factors for $\mathrm{OHB}$ reactivation include anti-HBs negativity or its reduction in chemotherapy period, HBV genotype $B$ and the presence of the core or precore mutation (6).

The severity and duration of immunosuppression have an important role in triggering reactivation of $\mathrm{HBV}$ infection (3). More severe and frequent reactivation has been reported during hematologic diseases, chemotherapy employed in hematologic malignancies, and allogeneic bone marrow or organ transplantation which elicits more severe and prolonged immunosuppression than homologous bone marrow transplantation or solid tumor chemotherapy (3). 


\begin{tabular}{|l|l|}
\hline \multicolumn{2}{|l|}{ Table 1. Conditions associated with occult hepatitis B reactivation (5) } \\
\hline Clinical conditions & Therapies \\
\hline Hematological malignancies & - ABVD: Adriamycin+Bleomycin+Vinblastine+ Dacarbazine \\
- Non-Hodgkin lymphoma & - BEAM: Carmustine+Etoposide+Cytarabine+Melphalan \\
- Hodgkin lymphoma & - CHOP: Cyclophosphamide+Adriamycin/Doxorubicin+ Vincristine+ Prednisone \\
- Multiple myeloma & - R-CHOP: Rituximab or CHOP \\
- Myelo-monoblastic acute leukemia & - R-FND: Rituximab+Fludarabine+Mitoxantrone+ Dexamethasone \\
- Chronic lymphocytic leukemia & - VAD: Vincristine+Adriamycine+Dexamethasone \\
Transplantation & - Temozolomide \\
- Hematopoietic stem cell transplantation & - Rituximab (anti CD20) \\
- Liver transplantation & - Alemtuzumab (anti CD52) \\
- Bone marrow transplantation & - Adalimumab \\
- Kidney transplantation & - Tocilizumab \\
HIV infection & - Abatacept \\
Rheumatoid arthritis & - Infliximab (anti TNF alfa) \\
Glioblastoma & - Etanercept \\
& - Corticosteroids \\
& - Methotrexate \\
& - Leflunomide \\
& - Bucillamin \\
& - Valproic acid \\
& - Romidepsin \\
\hline
\end{tabular}

It has also been reported that $\mathrm{OHB}$ individuals may frequently change their HBV serological profile if immunocompromised, although only a minority of these cases develop clinically typical acute hepatitis, and there are studies indicating $\mathrm{HBsAg}$ re-seroconversion in patients undergoing hematopoietic stem cell transplantation or receiving rituximab-containing chemotherapy $(7,8)$.

All patients receiving immunosuppressive treatment should be tested for HBV serological markers, including anti-HBc especially before starting therapy $(2,5,6)$. Prophylactic antiviral treatment in hemato-oncological patients with possible $\mathrm{OHB}$ (isolated anti-HBc positivity) is still controversial. Testing these patients for HBV DNA and treating them as HBsAg-positive subjects when viral DNA is detectable are recommended, whereas when it is undetectable, they should be followed carefully by means of alanine aminotransferase (ALT) and HBV DNA testing up to a year after the end of immunosuppressive treatment. Confirmation of HBV reactivation by HBV DNA ( $>30$ $\mathrm{IU} / \mathrm{ml}$ ) or a highly sensitive HBsAg assay (low limit of detection $<0.1 \mathrm{ng} / \mathrm{mL}$ ) before ALT elevation is required for beginning antiviral therapy $(2,5,6,9)$.

Not only prophylaxis with antiviral agents, but also prior HBV immunization with an optimal anti-HBs response can prevent reactivation of $\mathrm{OHB}$ in most of transplant cases with $\mathrm{HBsAg}$ negativity and anti-HBc positivity $(6,9)$. There is no necessity for testing HBV DNA before immunosuppressive therapy in patients with serological evidence of natural immunity of HBV due to past infection (anti-HBs $>10 \mathrm{IU} / \mathrm{ml}$ ). In these cases, following carefully by ALT is reasonable and they are not candidates for prophylactic antiviral treatment $(6,9)$.

\section{References}

1. Uyanıkoglu A, Sert U, Nar H, Yenice N. Occult Hepatitis B Reactivation After Chemoteraphy: A Case Report. Viral Hepat J. 2015;21:56-58.

2. Raimondo G, Allain JP, Brunetto MR, Buendia MA, Chen DS, Colombo M, Craxi A, Donato F, Ferrari C, Gaeta GB, Gerlich WH, Levrero M, Locarnini S, Michalak T, Mondelli MU, Pawlotsky JM, Pollicino T, Prati D, Puoti M, Samuel D, Shouval D, Smedile A, Squadrito G, Trépo C, Villa E, Will H, Zanetti AR, Zoulim F. Statements from the Taormina expert meeting on occult hepatitis B virus infection. J Hepatol. 2008;49:652-657.

3. Said ZNA. An overview of occult hepatitis B virus infection. World J Gastroenterol. 2011;17:1927-1938.

4. Samal J, Kandpal M, Vivekanandan P. Molecular Mechanisms Underlying Occult Hepatitis B Virus Infection. Clin Microbiol Rev. 2012;25:142-163.

5. Raimondo G, Caccamo G, Filomia R, Pollicino T. Occult HBV infection. Semin Immunopatho. 2013;35:39-52.

6. Zobeiri M. Occult hepatitis B: clinical viewpoint and management. Hepat Res Treat. 2013;2013:259148.

7. Papamichalis P, Alexiou A, Boulbou M, Dalekos GN, Rigopoulou El. Reactivation of resolved hepatitis $B$ virus infection after immunosuppression: is it time to adopt preemptive therapy? Clin Res Hepatol Gastroenterol. 2012;36:84-93.

8. Watanabe $M$, Shibuya $A$, Tsunoda $Y$, Danbara $M$, Ishii $R$, Ohsaka M, Takada J, Tanaka Y, Okuwaki Y, Minamino T, Hidaka H, Nakazawa T, Horie R, Higashihara M, Koizumi W. Re-appearance of hepatitis $B$ virus following therapy with rituximab for lymphoma is not rare in Japanese patients with past hepatitis B virus infection. Liver Int. 2011;31:340-347.

9. Lledo JL, Fernandez C, Gutierrez ML, Ocana S. Management of occult hepatitis B virus infection: an update for the clinician. World J Gastroenterol. 2011;17:1563-1568. 